\title{
EXCAVATIONS AT SHUNI, ISRAEL
}

\author{
W.J. Henderson, Rand Afrikaans University
}

\section{Introduction}

The area known today as Israel has a long and rich history quite out of proportion to its geographical size. It has been a major focal point of archaeological interest since the early 19th century (Macalister 1925:13-75; Albright 1949:23-48), and this archaeological activity has continued since the creation of the modern State of Israel in 1948. Everywhere archaeological sites have been and are being identified and excavated. "Size for size", writes Edward Bacon (1971:171), "there is probably more controlled native archaeological activity in Israel than in any other country in the world."

A series of sensational developments caught the interest of people all over the world: the discovery of the Dead Sea Scrolls in 1947, and the ruins of Qumran and further book-rolls in other caves in the 1950s (Davies 1982); the excavation of Masada by Yigael Yadin from 1963 to 1965 (Yadin 1966); the diggings at the City of David in Jerusalem by Yigal Shiloh during the late 70s and early 80s (Shiloh 1985:451-462); the discovery in 1986 of the Kinneret (Sea of Galilee) boat, dating from between the 1st century BC and the 1st century AD, and now undergoing seven years of painstaking preservation and restoration at the Yigal Allon Museum at Kibbutz Ginosar (Peachey 1990); the discovery of a bronze calf at Ashkelon in August 1990 (Time International no. 32, 6/8/1990,56); and the continuing excavations at Bet She'an, begun in 1922 (Macalister 1925:73-74; Yadin \& Geva 1984:187-189) and still gradually revealing sections of the Scythian-Hellenistic city of Scythopolis, a large part of which still lies buried two or three metres below the surface.

In July 1990 Dr Bill Domeris (Dept. of Religious Studies, Wits) led a group of teachers and students from the University of the Witwatersrand and the Rand Afrikaans University on an archaeological trip to Israel to take part in excavations at Shuni, near Caesarea. This article aims to publicize the excavations and finds at Shuni in order to stimulate interest among other volunteer-excavators who may wish to participate in this exciting venture during the next two or three years and experience the thrill of an archaeological dig.

Since most of the recent archaeological material is still unpublished, photographs, drawings, diagrams or specific details of some of the finds are not yet available. For such material the archaeologists have priority rights to publication. One published report by the chief archaeologist Eli Shenhav (1990) has come to my attention.1 What is presented here is therefore based on my personal observations and research.

\section{Shuni}

Shuni lies about $6 \mathrm{~km}$. north-east of Caesarea, along the road to Binyamina and Zikhron Ya'aqov, two of the settlements founded and funded for returning Jews during the 19th century by the French Baron Edmond de Rothschild. The region, situated in the Valley of Nadiv, is fertile and well-suited to agricultural production. The vineyards started producing the famous Carmel wines in 1886.

1 I wish to thank Dr W.R. Domeris and Renata Rabichev of the University of the Witwatersrand for providing me with a copy of the article and a translation. 
The core of Shuni is the Jabotinsky Park, a site at present being developed for purposes of recreation (youth camps, hikes) and culture (local history, theatre, archaeological remains). The site is dominated by a fortress-like structure and buildings built over the remains of a Roman theatre situated on a hill. This hill slopes southeastwards to a valley of vineyards, fruit-trees and vegetables. Behind the theatre to the northwest rise hills, ending eventually in Mt Carmel whose wooded cliffs overhang Haifa.

The ancient name of Shuni is variously given as Ma'mas (Smith 1931: plate VII), Mamas (Zangemeister 1890:25); Miamas (Abel 1967:1, carte IV), Mijamas (Zangemeister 1890:25), Ma-ma- (Atlas 1970:IX/10), or Maimas (Shenhav 1990:58) from the Hebrew maim, "water". And indeed the local springs already in the late 2nd century AD gave rise to the establishment of what is presumably an Asklepeion (Aesculapium) or sanctuary of the healing-god Asklepios (or Aesculapius). Such a sanctuary was a kind of health spa, to which people with all kinds of ailments came to be cured by the spring-water.

The spa was still in use in the Byzantine period (330-640 AD). The earliest certain reference to the site was made in AD 333 by a Christian pilgrim from Bordeaux who in his Itinerarium Burdigalense (585-586 = Geyer \& Cuntz 1965:13; Shenhav 1990:58) recorded the following for the region of Caesarea: Inde est tertio miliario mons Syna, ubi fons est, in quem mulier est laverit, gravida fit. The Latin is improved though not entirely corrected in a later excerpt: In monte Syna est fons in qua si mulier laverit, gravide (sic) fiet. The sense is clear: "From there at the third mile-stone is mount Syna, where there's a spring, and if a woman washes herself in it, she becomes pregnant"). The buildings were destroyed during the Samaritan rebellion of 484 , but some reconstruction was undertaken, mainly to obliterate the signs of pagan worship and activities (Shenhav 1990:61). Further damage was done in the 6th century when Justinian legislated against non-Christian religious practices, and the theatre was converted into a secular olive-oil factory (Shenhav 1990:62). During the Crusades the cavea was filled in and a fortress erected over the site (Shenhav 1990:62).

A detailed description of the site and its ruins was given in 1870 by the French geographer and historian, Victor Geren: "At 5.15 we arrived at the arid land of Maimas, which is sometimes referred to as Um-Aliamas. This is the ruin of an ancient castle on a not very high hill, with a straight front and a semi-circular back, thus creating the shape of a theatre. There are several corridors, not yet broken, in a circular shape, built of hewn stones. They were probably built before the Crusades. In other parts of this fortress, especially in the tower where loopholes are situated, a building of a more recent period can be seen. The ruins of the fortress are nowadays used as a shelter for cattle. At the foot of the hill of the fortress I saw several granite columns, lying on the ground next to hewn stones, the ruins of a collapsed building. In close proximity I saw traces of a water source which led the waters of Zabarin to Caesarea" (Geren 1984:236-237; quoted by Shenhav 1990:59).

The actual identification of the theatre-shaped row of buildings above-ground was made during the comprehensive survey of the region by the Palestine Exploration Fund of the British Mandate from 1871 to 1877 . The results, published from 1881 to 1884 as the Survey of Western Palestine, in 7 volumes, comprised detailed accounts of the topography, archaeology, zoology and botany of the area. Two members of the survey-team, Conder and Kitchener, measured the site and realized that there was a Roman theatre below the surface (Conder \& Kitchener 1882:66-67; Zangemeister 1890:28; Shenhav 1990:59).

By 1907 the site had been greatly altered. Count Von Mülinen (1907:240-242; quoted by Shenhav 1990:59) described it as follows: "We are turning south into the road to Maimas, which lies at the foot of the mountain, and which today is usually called A-Shuni (Asam). This village is the property of the Chori-family. In it there is a big double-storey building with two yards. In the areas bordering with the Taninim river, for example in Bal-Itzur, there are plantations of mulberry used in the silk-industry. The raw material of moths, whose 
growth is watched over by Lebanese, is sent to Beirut for continuation of gestation. As a result of the establishment of a new building-project, which contains 15 districts, the ruins of the Roman theatre as well as the fortress described by ancient travellers have disappeared."

From the above a general picture emerges. When the complex fell into disuse and the main activity became agriculture, the cavea of the theatre and the attached buildings were put to more mundane use as factories and storehouses. Gradual decay and changed circumstances over many centuries took their toll: the ruins were demolished, the building-materials re-used, and the cavea filled in and levelled so that only the top row of blocks of the back seats and the stage remained visible in the shape of a stirrup. Arab settlers inhabited the area and built their houses on the row of stones sticking out above the ground, little suspecting or caring that the foundations of their dwellings were in fact the top course of an entire Roman theatre. In the years of the Israeli struggle for independence the fort at Shuni also played its part as the focalpoint of anti-Arab action. After 1948 the area was developed for agriculture, and especially for wine. The present excavations owe their beginning to an attempt by the owner of the vineyard to erect buildings alongside the modern tarred road that runs between the fort and the vineyard. The unearthing of a section of Roman road a mere half-metre under the ground not only put paid to any building-plans, but resulted in the loss of a considerable proportion of the vineyard under which stretch the foundations of a Roman settlement.

\section{The excavations}

Systematic excavation of the site began in 1987 under the auspices of the Jewish National Fund and the Department of Antiquities. The archaeologist of the Jewish National Fund, Eli Shenhav, has been assisted by a team of specialists, including Dr Yochi Mintsker and Dr Vasilius Tsfiris of the Department of Antiquities. The project is expected to continue until the end of the 1992/1993 season.

Apart from a small permanent staff of professional archaeologists and their assistants, there is a large contingent of volunteers from Israel itself and from various other countries. The system followed is that used by Yadin at Masada (Yadin 1966:13-14) and at most sites in Israel today. These amateur diggers (for they do most of the actual removal of soil!) must pay their own fares to and from Israel, and must be prepared to work hard and put up with somewhat less than luxurious sleeping-quarters. But for the duration of the dig, a minimum of two weeks, they receive free accommodation and three meals per day. To avoid the worst heat and humidity, the actual digging takes place from 5:30 to 12:30, with breaks for breakfast at 8:30 and for fruit at 10:30. Afternoons are devoted to pottery-washing (by the part-time volunteers) or administration (by the permanent staff).

Naturally, the excavations are conducted with the care and adherence to scientific methods that characterize archaeology today. A surveyor first draws up a masterplan of the entire site, complete with measurements, geographical features, scales, coding of areas. Areas of 5 metres square are measured off, staked, marked with string and numbered according to the masterplan. Each day's progress is recorded on site by the archaeologist and his assistants both in notebooks and on a diagram. All finds within a block are placed in a bucket with a label bearing the code-number of the particular block. Removal of the soil must be carried out strictly in layers (strata) according to the colour and texture of the soil. The digging of holes and the removal of too much soil all at once elicit immediate cries of displeasure from the archaeologists. After each layer or stratum has been uncovered, photographs are taken in the morning and late afternoon, so that shadows throw the uncovered stonework into relief. The soil is carried in a rubber bucket to a heap where it is sifted for coins. Metal detectors are also used to pinpoint buried coins or pieces of metal. These are placed in plastic packets and sent to laboratories for cleaning and analysis. 
The archaeological site is divided into three main areas: the theatre (A), the area surrounding the theatre to the south and southeast (B), and the area to the east of the theatre across the present tarred road (C). To date the excavations have brought a great variety of material to light in all three areas.

\subsection{Area A}

The Roman theatre has now been completely uncovered, and is being restored for modern use. It was built late in the 2 nd or early in the 3 rd century $A D$, and seated about a thousand spectators. After the Samaritan rebellion of 484 , the theatre was partially rebuilt and the orchestra enlarged by filling it up past the front row of seats and putting down a new floor quarried from the seats. During the excavations this Byzantine floor was removed after the necessary recording of details and measurements by means of photographs, sketches and reports. The Roman floor underneath, paved with local limestone slabs measuring $50 \mathrm{~cm}$ by $30 \mathrm{~cm}$, was found intact - the only such floor in Israel. In the centre of the orchestra, which is 20 metres in diameter, is a marble slab of $90 \mathrm{~cm}$ square, probably marking the position of an altar to Dionysus or his mother Semele (Shenhav 1990:60). Two rosette-shaped openings in the floor served to drain water from the orchestra.

The wall of the proscaenium is well-preserved with three niches and two recesses in the shape of seats (probably for statues) still clearly visible between them. The scaena itself, however, is severely damaged, though the protrusions in the proscaenium wall and the back wall or scaenae frons indicate where the wooden floor-boards of the stage were supported. Pieces of marble and granite columns are all that is left of the decoration. Beneath the stage was the hyposcaenium, the actors' dressing-rooms, the floor of which is paved with white slabs in a very good state of preservation (Shenhav 1990:60).

The other typical features of a Roman theatre are discernible but barely preserved: the terraces surrounding the orchestra, the seats, the low wall dividing the orchestra from the seating, and the seat of honour, tribunal, in the middle.

Inside the cavea an olive-press, with its typical massive circular stones for maximum pressure on the olives, was discovered in situ. Nearby are the remains of a double oven for evaporating residual water from the olive-oil. These are relics of the period from the 6th to the 8th centuries when the theatre became a factory and work-place for agriculture (Shenhav 1990:62).

\subsection{Area B}

In the area outside the theatre archaeological probes have been made as part of the initial survey of the entire complex. Some foundations and wall-sections of buildings, perhaps houses, a few with mosaic paving, have been exposed. A great deal of work still has to be done on this part.

Of the network of water-conduits that supplied the baths, only a few trenches, cisterns and some pools have been found. A water-source that fed the theatre from the spring of Um-ElAlak has been found (Shenhav 1990:61). The terrain slopes down from behind the theatre to the Roman road at the edge of the valley, providing the necessary pressure for the water-flow. It is only a matter of time before further stretches of tunnels and even baths are found. 


\subsection{Area C}

This is the area where the South African group did most of its work. About $0,5 \mathrm{~km}$. of a Roman road has been uncovered, in very good condition, straight, constructed with large basalt rocks, curved to allow rainwater to drain to the sides, and with a kerb of stone blocks. On either side are remains of the water-draining system and the foundations of buildings which lined the street.

At one point alongside the road, on the pavement, the silted up opening of a drain was discovered. After three days of careful digging and removal of the fine, compacted soil, a barrel-shaped "bridge" of Roman concrete, which supported the pavement over the trench at right angles to the road, was revealed. On the fourth day two intact earthenware jugs were discovered embedded in the sediment high up against the ceiling of the tunnel.

Further along, the road is intersected by another leading west to the theatre and east into the vineyard. On both sides of the road at the intersection are the bases of columns still in situ. In another well nearby a complete section of lead piping, peculiarly connected to a ceramic pipe, was laid bare.

Between the foundations of the buildings next to the road a large quantity of broken pottery and roof-tiles, a number of coins, and a few clay oil-lamps from the Roman, Byzantine and Arabian periods have come to light, as well as some large iron nails of Roman design and fragments of thin, blue-green Byzantine glass. The potsherds, of course, provide the material for dating the various strata.

A further significant find is a section of foundation typical of Hellenistic patterning, covered by the later Roman foundations. If original (and there are as yet no contra-indications), this piece of evidence would date the use of the terrain further back into the past, somewhere between the 3rd and 1st centuries BC. Further uncovering of this Hellenistic foundation may provide some surprises.

At its southern end the road disappears under the modern road; the northern end, where work is under way, continues at a depth of only about $30-50 \mathrm{~cm}$. under the fields and a mangogrove, and heads straight for a grass-covered artificial heap about $0,5 \mathrm{~km}$. further. Are the remains of the expected temple buried beneath this mound?

\subsection{Inscriptions}

Two inscriptions, one in Latin, the other in Greek, were discovered in the late 19th century. The Greek inscription offers little in the way of difficulties or information.

ANTRNINOY
KAI KYROY
TEKNA CA
MOYH $O Y$
Shalom (in Hebrew)

"(The burial site) of Antoninus and Kyros (set up by) the sons of Samuel. Shalom."

The possessive genitive to indicate the name of the person whose tomb is marked by the inscription, is not unknown in Greek epigraphy (cf. e.g. Dittenberger 1960:I, no.1). Nothing is known of the Antoninus or Cyrus named here. The dating is uncertain. The farewell "shalom" in Hebrew script is equivalent to the Christian requiescat in pace, which points to the Byzantine period, perhaps late 3rd to early 4th century AD. There is some cultural interest in the fact that the children of a Jew, Samuel, dedicated the tomb to a Roman Antoninus and a 
"Persian" Cyrus, and even used Hebrew in the Greek inscription. It says much for the "international" character and interrelationships of the local community.

The Latin inscription offers far more that is of interest:

M(arcum) Fl(avium) Agrippam Pontif(icem)

II viral(em) col(oniae) I (primae) Fl(aviae)

Aug(ustae) Caesareae oratorem ex dec(urionum)

dec(reto) pec(unia) publ(ica)

(CIL III, no.12082).

"To Marcus Flavius Agrippa, priest, duumvir of Colonia Prima

Flavia Augusta Caesarea, speaker by decree of the decuriones, (this monument was raised) by public expense."

The inscription appears on a granite column on which once stood a statue of the dedicatee. His name and titles are given in the accusative, a Greek format in which a verb such as anethêke/anethêsan or etimêseletimêsan, and an issuing authority such as the polis, dêmos or boule are often omitted. This format is also encountered in Latin inscriptions (e.g. CIL I.533, 596; III.6712-14, 6754; cf. Zangemeister 1890:29; Cagnat 1914:259 n.1; Sandys 1927:9495), where the verb honoravit/honoraverunt and the issuing authority must be understood. The monument was probably erected to commemmorate the role of Agrippa in acting as "speaker", or legate, on behalf of Caesarea (Zangemeister 1890:28-29).

Caesarea had been built by Herod between 22 and $10 \mathrm{BC}$ on the site of the earlier Straton's Tower. On being proclaimed emperor with the support of the legions in Judaea and Syria in 69 (Tac. Hist. 2.79; Suet. Vesp. 6), Vespasian turned Caesarea into a tribute-free colony with the name Colonia Prima Flavia Augusta Caesarea. The description prima proclaimed it as the first colony established by Vespasian (Zangemeister 1890:26-27). That the commemorative column had been set up in Shuni, $6 \mathrm{~km}$. from Caesarea itself, is an indication of the extent of the colony's territory (Zangemeister 1890:28).

On the basis of the form of the writing and the names of the dedicatee the inscription can be tentatively dated to the time of Trajan or Hadrian. M. Flavius Agrippa probably received his Roman names either shortly after birth, or on his or his father's receiving Roman citizenship. "Flavius" clearly refers to a Flavian emperor, while "M. Agrippa" recalls M: Iulius Agrippa (10 BC - AD 44), a grandson of Herod the Great, or the former's son, M. Iulius Agrippa (AD 27/28-c.93/94), the last of the Idumaean kings of Judaea. The names may indicate some close association between our Agrippa and his family and the rulers of the area (Zangemeister 1890:29-30).

An intriguing suggestion is put forward by Zangemeister (1890:30) that the M. Flavius Agrippa of the inscription may have been the son of Josephus, the Jewish historian honoured in 70 with Roman citizenship by Vespasian, whose nomen gentilicum he adopted. This son by his third wife was born in 77 or 78, and is referred to as Agrippa in Josephus' Vita (cc.1 and 76). If one allows the prescribed minimum age of 25 for the duumvirate, this Agrippa would have become duumvir after 101/102. The commemorative column and statue would then have been erected soon after that.

\subsection{An Asklepeion?}

Besides the theatre itself the most important single find has been a marble statue, provisionally identified as Asklepios (Shenhav 1990:61). The figure is smaller than life-size, bearded and naked. This last characteristic is unknown in portrayals of Asklepios (see Roscher 1965:1.1,632-640). His traditional symbols, the staff and snake (Roscher 
1965:1.1,627-630), are also absent.

Certain identification of the figure as Asklepios, as well as of the entire complex as an Asklepeion, still awaits decisive confirmation. The general set-up is typical of a sanctuary of Asklepios: natural springs, water-conduits, a theatre, a rural setting, dating to the 4th century (when the cult was very popular; Schneider 1969:815; Walton 1970:129-130). The matter would be settled by the discovery of the remains of a temple, baths, gymnasia, or the "hotel" where visitors seeking cures were accommodated; inscriptions recording remedies or successful treatment; assorted medical instruments; or representations of healed parts of the body (arms, legs, eyes, ears, female breasts, chest, stomach, lungs, diaphragm, digestive organs), offered in thanks to the god. These votive offerings are numerically the largest category of artefacts found at other sanctuaries of Asklepios, portrayals of the god himself being much rarer (Schneider 1969:817). Such an hotel, medical instruments and an ex voto relief of ears have been found at the great Asklepeion at Epidaurus (illustrations in Voutsas 28-29, 36).

\section{Conclusion}

Whatever further discoveries are made at Shuni, the site is already of primary importance for science. The Roman theatre and section of Roman road, both in an excellent state of preservation, are in themselves significant for our knowledge of the infrastructure of Roman Palestine. The Hellenistic foundations, some of the pottery and coins, the "Asklepios" statue, and the emerging components of what may well turn out to be a sanctuary of Asklepios, similar to but smaller than those at Kos and Epidauros, add further interest.

For anyone interested in archaeology, the opportunity to go on a real, live "dig" - and that on a Roman site - is not to be missed. The experience of taking objects of more than two thousand years old directly from the soil is worth the expense and effort (neither of which is minimal). In the next year or two more of the road will be uncovered, and it will become clear whether it leads to a temple or other public building. It would be an added bonus for the South African contingent (known as "The Dust-Busters") if they were in on such significant discoveries.

\section{REFERENCES}

Abel, Le P. F.-M. 1967. Géographique de la Palestine. Paris: J. Gabalda.

Albright, W.F. 1949. The archaeology of Palestine. Harmondsworth: Penguin Books.

Atlas of Israel. 1970. Jerusalem/Amsterdam: Survey of Israel, Department of Labour/Elsevier.

Bacon, E. 1971. Archaeology. Discoveries in the 1960s. London: Cassell.

Cagnat, R. 1914. Cours d'épigraphie latine. Paris: Fontemoing et cie.

Conder, C.R. \& Kitchener, H.H. 1882. Survey of Western Palestine, vol. 2. London: Palestine Exploration Fund.

Davies, P.R. 1982. Qumran. Guildford: Lutterworth Press.

Dittenberger, W. 1960. Orientis Graeci inscriptiones selectae. Hildesheim: Georg Olms.

Geren, V. 1984. The geographical, historical and archaeological description of the land of Israel. Jerusalem: Shomron. 
Geyer, P. \& Cuntz, O. (eds.). 1965. Itinerarium Burdigalense, in: Corpus Christianorum. Series Latina 175, 1-26. Turnholt: Brepols.

Macalister, R.A.S. 1925. A century of excavation in Palestine. London: The Religious Tract Society.

Peachey, Claire. 1990. "Model building in nautical archaeology. The Kinneret boat". Biblical Archaeologist 53.1, 46-53.

Roscher, W.H. 1965. Lexikon der griechischen und romischen Mythologie. Leipzig: Georg Olms.

Sandys, J.E. 1927. Latin epigraphy. An introduction to the study of inscriptions. London: Macmillan.

Schneider, C. 1969. Kulturgeschichte des Hellenismus, vol.2. Munich: C.H. Beck.

Shenhav, E. 1990. "Shuni/Maimas. Identification and history of the site". Qadmoniot ("Antiquities") 23.2, 59-62 [in Hebrew].

Shiloh, Y. 1985. "The City of David: 1978-1983", in: Janet Amitai (ed.), Biblical Archaeology Today. Proceedings of the International Congress on Biblical Archaeology, Jerusalem, April 1984:451-462. Jerusalem: Israel Exploration Society.

Smith, G.A. 1931. The historical geography of the Holy Land. London: Hodder and Stoughton.

Von Mülinen, E. 1907. "Beiträge zur Kenntniss des Karmel". Zeitschrift des Deutschen Paldstina-Vereins 30, 240-242.

Voutsas, C. n.d. Epidauros and museum. Athens.

Walton, F.R. 1970. "Asclepius", in: N.G.L. Hammond \& H.H. Scullard (eds.), The Oxford Classical Dictionary, 129-130. Oxford: Clarendon Press.

Yadin, Y. 1966. Masada. Herod's fortress and the Zealots' last stand. London: Weidenfeld and Nicolson.

Yadin, Y. \& Geva, S. 1984. "Tel Beth Shean, 1983". Israel Exploration Journal 34, 187189.

Zangemaister, K. 1890. "Inschrift der Vespasianischen Colonie Caesarea in Palästina". Zeitschrift des Deutschen Palastina-Vereins 13, 25-30. 